\title{
Front Matter: Volume 10377
}

, "Front Matter: Volume 10377," Proc. SPIE 10377, Optical System Alignment, Tolerancing, and Verification XI, 1037701 (22 November 2017); doi:

10.1117/12.2296904

EDIE Event: SPIE Optical Engineering + Applications, 2017, San Diego, California, SPIE. United States 


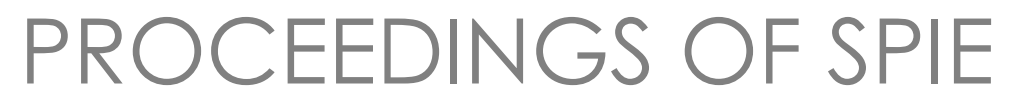

\section{Optical System Alignment, Tolerancing, and Verification XI}

José Sasián

Richard N. Youngworth

Editors

6-7 August 2017

San Diego, California, United States

Sponsored and Published by

SPIE

Volume 10377 
The papers in this volume were part of the technical conference cited on the cover and title page. Papers were selected and subject to review by the editors and conference program committee. Some conference presentations may not be available for publication. Additional papers and presentation recordings may be available online in the SPIE Digital Library at SPIEDigitalLibrary.org.

The papers reflect the work and thoughts of the authors and are published herein as submitted. The publisher is not responsible for the validity of the information or for any outcomes resulting from reliance thereon.

Please use the following format to cite material from these proceedings:

Author(s), "Title of Paper," in Optical System Alignment, Tolerancing, and Verification XI, edited by José Sasián, Richard N. Youngworth, Proceedings of SPIE Vol. 10377 (SPIE, Bellingham, WA, 2017) Seven-digit Article CID Number.

ISSN: 0277-786X

ISSN: 1996-756X (electronic)

ISBN: 9781510612112

ISBN: 9781510612129 (electronic)

Published by

SPIE

P.O. Box 10, Bellingham, Washington 98227-0010 USA

Telephone +1 3606763290 (Pacific Time) · Fax +1 3606471445

SPIE.org

Copyright @ 2017 , Society of Photo-Optical Instrumentation Engineers.

Copying of material in this book for internal or personal use, or for the internal or personal use of specific clients, beyond the fair use provisions granted by the U.S. Copyright Law is authorized by SPIE subject to payment of copying fees. The Transactional Reporting Service base fee for this volume is $\$ 18.00$ per article (or portion thereof), which should be paid directly to the Copyright Clearance Center (CCC), 222 Rosewood Drive, Danvers, MA 01923. Payment may also be made electronically through CCC Online at copyright.com. Other copying for republication, resale, advertising or promotion, or any form of systematic or multiple reproduction of any material in this book is prohibited except with permission in writing from the publisher. The CCC fee code is 0277 $786 \times / 17 / \$ 18.00$.

Printed in the United States of America.

Publication of record for individual papers is online in the SPIE Digital Library.

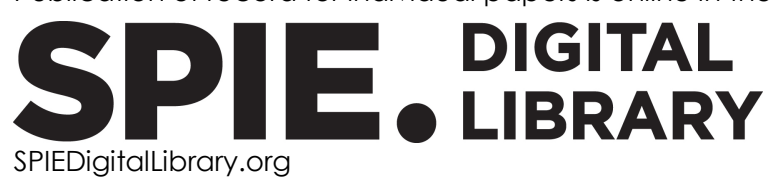

Paper Numbering: Proceedings of SPIE follow an e-First publication model. A unique citation identifier (CID) number is assigned to each article at the time of publication. Utilization of CIDs allows articles to be fully citable as soon as they are published online, and connects the same identifier to all online and print versions of the publication. SPIE uses a seven-digit CID article numbering system structured as follows:

- The first five digits correspond to the SPIE volume number.

- The last two digits indicate publication order within the volume using a Base 36 numbering system employing both numerals and letters. These two-number sets start with $00,01,02,03$, 04, 05, 06, 07, 08, 09, 0A, OB ... 0Z, followed by 10-1Z, 20-2Z, etc. The CID Number appears on each page of the manuscript. 


\title{
Contents
}

\author{
$\checkmark \quad$ Authors \\ vii Conference Committee \\ ix Introduction
}

\section{SESSION 1 VERIFICATION AND SYSTEM ALIGNMENT}

1037702 Sub-cell turning to accomplish micron-level alignment of precision assemblies [10377-1]

1037703 Tolerancing a lens for LED uniform illumination [10377-15]

1037704 Photonic Doppler velocimetry probe used to measure grain boundaries of dynamic shocked materials (Invited Paper) [10377-3]

1037706 Integrated confocal Raman probe combined with a free-form reflector based lab-on-chip [10377-5]

\section{SESSION 2 OPTICAL TOLERANCING}

1037707 Understanding product cost vs. performance through an in-depth system Monte Carlo analysis (Invited Paper) [10377-7]

1037708 Specifying tilts, decenters, and beam deviations using the new edition of ISO 10110-6 [10377-8]

1037709 Specification and tolerancing of bulk glass material imperfections with ISO standards [10377-9]

10377 OA Generalized surface contributions for misalignment sensitivity analysis [10377-10]

\section{SESSION $3 \quad$ ALIGNMENT OF OPTICAL SYSTEMS I}

10377 OB Optical alignment using a CGH and an autostigmatic microscope [10377-11]

10377 OC Measurement of low-order aberrations with an autostigmatic microscope [10377-12]

10377 OD Review of Zernike polynomials and their use in describing the impact of misalignment in optical systems (Invited Paper) [10377-13]

10377 OE Ground to on-orbit alignment study of the WFIRST wide-field channel and resulting changes in the telescope architecture [10377-25] 
10377 OF SFR test fixture for hemispherical and hyperhemispherical camera systems [10377-2]

\section{SESSION 4 ALIGNMENT OF OPTICAL SYSTEMS II}

10377 OG Simultaneous angular alignment of segmented mirrors using sinusoidal pattern analysis [10377-16]

$10377 \mathrm{OH} \quad$ Alignment and testing of critical interface fixtures for the James Webb Space Telescope [10377-17]

10377 Ol Metrology for trending alignment of the James Webb Space Telescope before and after ambient environmental testing [10377-18]

10377 OJ Assembly, alignment and test of the Transiting Exoplanet Survey Satellite (TESS) optical assemblies [10377-19]

10377 OK High-precision laser microcutting and laser microdrilling using diffractive beam-splitting and high-precision flexible beam alignment [10377-20]

\section{POSTER SESSION}

$10377 \mathrm{OL}$ Calculation of lens alignment errors using the ray transfer matrices for the lens assembly system with an autocollimator and a rotation stage [10377-21]

10377 OM Self-compensation for trefoil aberration of symmetric dioptric microlithographic lens [10377-22]

1037700 Raman laser spectrometer optical head: qualification model assembly and integration verification [10377-24] 


\section{Authors}

Numbers in the index correspond to the last two digits of the seven-digit citation identifier (CID) article numbering system used in Proceedings of SPIE. The first five digits reflect the volume number. Base 36 numbering is employed for the last two digits and indicates the order of articles within the volume. Numbers start with $00,01,02,03,04,05,06,07,08,09,0 A, 0 B . .0 Z$, followed by 10-1Z, 20-2Z, etc.

Andre, James E., OJ

Armani, Nerses, $\mathrm{OE}$

Bagdanove, $\mathrm{Paul}, \mathrm{OH}$

Balonek, Gregory, 0J

Barbieri, Giancarlo, 06

Bartusek, Lisa, OE

Belenguer, T., 00

Berrier, Joshua, $\mathrm{OH}, \mathrm{Ol}$

Brown, Joshua J., OJ

Buss, Christian, 02

Canchal, R., 00

Canora, C. P., 00

Casey, Tom, OE

Chesbrough, Christian D., OJ

Cho, Sungwhi, OL

Choi, Heejoo, OG

Chrisp, Michael P., OJ

Chu, Jiyoung, OL

Clark, Kristin E., OJ

Clarke, Steven A., 04

Cofie, Emmanuel, $\mathrm{OH}$

Content, Dave, OE

Conturie, Yves, $\mathrm{OE}$

Dalpiaz, Michael, oJ

Dubin, Matthew, OG

Eichhorn, William, 0

Escribano, D., 00

Fensin, Saryu J., 04

Fornaroli, C., OK

Frayer, Daniel K., 04

Gao, Guangjun, OE

Gillner, A., OK

Glassman, Tiffany, $\mathrm{OH}$

Gordillo, C., 00

Gross, Herbert, 0A

Gum, Jeff, OI

Hadjimichael, Theodore, $\mathrm{OH}, \mathrm{OI}$

Hagopian, John, OE

Hayden, Joseph, 01

Ho, Cheng-Fang, OM

Holtkamp, J., OK

Hsu, Wei-Yao, OM

Jang, Sangdon, OL

Johnson, Eric, $\mathrm{OH}$

Jones, David R., 04

Joo, Won Don, OL

Jurling, Alden, $\mathrm{OE}$

Kaplan, Natan, OK
Kaufman, Morris I., 04

Khreishi, Manal, Ol

Kim, Dae Wook, OG

Krisiloff, Allen J., 09

Kuhn, William P., OC

Kumler, James J., 02

Lennon, Joseph, 0J

Levi, Joshua, $\mathrm{OH}$

Liu, Qing, 06

Lo, Amy, OH

Lopez-Reyes, G., 00

Malone, Robert M., 04

Marx, Cathy, OE

Marzouk, Joe, OE

McGillivray, Kevin D., 04

McLean, Kyle, $\mathrm{OH}, \mathrm{OI}$

McMann, Joseph, $\mathrm{OH}$

Moral, A. G., 00

Ohl, Raymond G., $\mathrm{OH}$, Ol

Oleszko, Mateusz, OA

Osgood, Dean, $\mathrm{OH}$

Ottevaere, Heidi, 06

Parker, James, $\mathrm{OH}$

Parks, Robert E., OB

Pasquale, Bert, $\mathrm{OE}$

Peng, Wei-Jei, OM

Prieto, J. A. R., 00

Ramos, G., 00

Redman, Kevin, $\mathrm{OH}, \mathrm{Ol}$

Richards, B. C., OJ

Roberts, Vicki, $\mathrm{OH}$

Rull, F., 00

Ryu, Jieun, 03

Sanson, Mark C., 07

Santiago, A., 00

Sanz-Palomino, M., 00

Sasian, Jose, 03

Schwiegerling, Jim, OD

Shachaf, Lior, OK

Smith, J. Scott, OE

Stephens, Matthew, $\mathrm{OH}$

Sullivan, Joseph, 0 I

Sutton, Adam, $\mathrm{OH}$

Tamkin, John M., OF

Tang, Hong, OE

Thienpont, Hugo, 06

Trumper, Isaac, OG

Wenzel, Greg, $\mathrm{OH}, \mathrm{Ol}$ 
Whipple, Arthur, OE

Williamson, Ray, 08

Young, Jerrod, $\mathrm{OH}, \mathrm{Ol}$

Zhao, Wenchuan, OG

Zibner, F., OK

Proc. of SPIE Vol. 10377 1037701-6

Downloaded From: https://www.spiedigitallibrary.org/conference-proceedings-of-spie on 26 Apr 2023 Terms of Use: https://www.spiedigitallibrary.org/terms-of-use 


\section{Conference Committee}

Program Track Chair

José Sasián, College of Optical Sciences, The University of Arizona (United States)

Conference Chairs

José Sasián, College of Optical Sciences, The University of Arizona (United States)

Richard N. Youngworth, Riyo LLC (United States)

Conference Program Committee

Matthew B. Dubin, College of Optical Sciences, The University of Arizona (United States)

Jonathan D. Ellis, University of Rochester (United States)

Sen Han, University of Shanghai for Science and Technology (China)

Marco Hanft, Carl Zeiss AG (Germany)

William P. Kuhn, Opt-E (United States)

Chao-Wen Liang, National Central University (Taiwan)

Norbert Lindlein, Friedrich-Alexander-Universität Erlangen-Nürnberg (Germany)

Robert M. Malone, National Security Technologies, LLC (United States)

Raymond G. Ohl IV, NASA Goddard Space Flight Center (United States)

Craig W. Pansing, Synopsys, Inc. (United States)

Robert E. Parks, Optical Perspectives Group, LLC (United States)

Brian C. Primeau, Ball Aerospace \& Technologies Corporation (United States)

Martha Rosete-Aguilar, Universidad Nacional Autónoma de México (Mexico)

Peng Su, ASML US, Inc. (United States)

Yana Z. Williams, Atlas Material Testing Technology (United States)

Session Chairs

1 Verification and System Alignment

Brian C. Primeau, Ball Aerospace \& Technologies Corporation (United States)

2 Optical Tolerancing

William P. Kuhn, Opt-E (United States) 
3 Alignment of Optical Systems I

Robert M. Malone, National Security Technologies, LLC (United States)

4 Alignment of Optical Systems II

Robert E. Parks, Optical Perspectives Group, LLC (United States) 


\section{Introduction}

The San Diego SPIE Optics and Photonics Symposium has provided a beautiful setting for a world-class conference for Optical System Alignment, Tolerancing, and Verification XI. As chairs of this conference, we are continually pleased with the technical content, authors, program committee, and SPIE. We find it difficult to express how thankful and humbled we are, by the community's and SPIE's support of a conference that embodies the traits of an international event. The 2017 conference had four sessions with excellent talks, in addition to some posters presented at the poster session. Of special note is that all presenters successfully submitted proceedings papers, for a total of 21 in the volume. Having $100 \%$ manuscript submission is excellent and this provides the community at large the technical content of the conference.

This year there were many highlights in the conference and we encourage the community to peruse the proceedings. We had a high value first session covering papers in alignment and verification topics. The second session involved a strong set of papers primarily covering tolerancing of optical systems, including coverage of two key international standards in the ISO 10110 drawing series. The sessions in the afternoon were both excellent, with papers on aligning optical systems, entailing not just alignment of specific systems but also methodology and hardware for aligning optical systems. The invited paper on Zernike polynomials and alignment was valuable, especially as it is useful to different fields including visual optics. The poster session was well attended and covered alignment of optical systems.

This conference will continue in 2018. We encourage everyone interested in optical system alignment, tolerancing, and verification to look for the call for papers and submit their work early 2018. Please feel free to contact us, or anyone in our program committee, for questions, requests or comments.

See you in San Diego in August 2018.

José Sasián

Richard N. Youngworth 
Proc. of SPIE Vol. 10377 1037701-10 Downloaded From: https://www.spiedigitallibrary.org/conference-proceedings-of-spie on 26 Apr 2023
Terms of Use: https://www.spiedigitallibrary.org/terms-of-use 